\title{
QUALITY OF ICE MILK SUPPLEMENTED WITH MANGO'S PEELS POWDER
}

\author{
K.M.K. Kebary, S.A. Hussein, R.M. Badawi and Fatma E. Eldhshan \\ Department of Dairy Sci. and Techno., Faculty of Agriculture, Menoufia University, Shibin \\ El-Kom, Egypt. \\ Received: Dec. 10, 2019 \\ Accepted: Jan. 9, 2020
}

\begin{abstract}
The effect of incorporated mango's peels powder on the physical, chemical and sensory properties of ice milk were studied. 5 ice milk batchy were prepared by adding $0.0,0.5,1.0,1.5$ and 2.0\% mango's peel powder. Obtained results indicated that adding mango's peel powder to ice milk mixes increased the specific gravity and weight per gallon, while did not affect significantly the acidity of ice milk mixes. Supplementing ice milk with mango's peels powder increased the specific gravity, weight per gallon, melting resistances, total solids and protein content of the resultant ice milk. Overrun did not change by adding mango's peel powder up to $1.0 \%$, while increasing the rate of adding mango's peel powder above that decreased the overrun. Although all ice milk treatments were accepted by the panelists ice milk treatments $T 1, T 2$ those made by adding 1.0 and 1.5\% mango's peel powder gained the highest scores of organoleptic properties and were the most acceptable ice milk treatments. The scores of organoleptic properties of all ice milk did not change during the 8 weeks of storage. Titratable acidity, total solids, fat total protein and ash contents did not change significantly during the storage period.
\end{abstract}

Key words: Ice cream, mango's peel powder.

\section{INTRODUCTION}

Ice cream which is the most popular frozen dessert in Egypt and all the world was made by mixing different ingredients such as milk, cream, milk solids non-fat, sugar, stabilizers, emulsifiers, flavours and calorurs (Arbuckle, 2013). It is highly accepted by children, adolescents, adults and elderly public. The production and consumption of frozen desserts have been increased tremendously recently in Egypt and all over the world because of its significance nutritional value, production of different forms and types, using a wide range of ingredients and flavours, production of low fat, low calories and low lactose products using frozen desserts as a carier for probiotics, prebiotics and nutraceuticals and finally using the frozen desserts as functional foods ( Kebary et al., 2015 and Kebary et al., 2018 ).
Dietary fiber is naturally present in cereals, vegetables, fruits and nuts. It is not digested by enzymes in the human intestinal tract, but part of it may be metabolized by bacteria in the lower gut. Dietary fibers are classified as soluble and insoluble fibers (Desmedt and Jacobs, 2001; Behall et al., 2006 and Lunn and Buttriss, 2007). Recently dietary fibers have received increasing attention from researchers and industry to incorporate dietary fibers in different foods and dairy products because of then crucial beneficial effects such as reducing of colon and heart related diseases, diabetes incidence, gut neoplasia, reducing the risk of colon cancer, preventing constipation and hemorrhoids, lowering blood cholesterol, regulating blood glucose levels for diabetes management, producing short chain fatty acids, increasing calcium absorption, 
stimulating the immune system and acting as prebiotics which enhance the growth of beneficial gut microflora(Pandiyan et al., 2012 ; Ahmadi et al.,2014; Hamed et al., 2014 ; Kamalyet al., 2017; Ayar et al., 2018 and Kebary et al., 2018). The recommended adequate intake of fibers is $25-38 \mathrm{~g}$ per day for adults $(14 \mathrm{~g} / 1000 \mathrm{kcal} / \mathrm{day})$. Yet, the diet of a substantial number of people in developed countries is insufficient to achieve the recommended daily intake of fibers. (King et al., 2012). In addition dietary fibers can be used as fat replacers, sugar replacers, a low caloric bulking agent, texturizing agent, water and oil binding agents and emulsification and gel formation agents (Meyer et al., 2011; Hamed et al., 2014; Kebary et al., 2015; Kamaly et al., 2017and Kebary et al., 2018).

Mango is one of the most cultivated fruit in the world. The world production of mango fruits was 35 million tons, while in Egypt it was 450 thousand tons in 2009 (FAO, 2009). There are several varieties grown in Egypt such as alphonse, zebda, mabroka, balady and succary (EISoukkary et al., 2000). Mango is a seasonal fruit; therefore $20 \%$ of fruit are processed for products such as puree, nectar, juice, pickles and canned slices. Peel, which is a major by- product during processing of mango contributes about $15-20 \%$ of the fruit (Beerh, 1976). In Egypt mango's peel and pulp fibers are discarded as a waste and become a source of pollution. It has been reported that mango's peel is a good source of polyphenols, carotenoids, vitamin E and C and dietary fibers. Also, it exhibited good antioxidant properties (Ajila et al., 2007; Kim et al., 2010).

Dairy products are not a good source of fibers however, they could prowide an alternative vehicle for the development of fibers enrich foods (Ozcan and Kuituldu, 2014).
The objectives of this study were investigating the effect of supplementing ice milk with mango's peel powder on physical, chemical and sensory attributes of ice milk and momitoring the changes of ice milk quality during storage.

\section{MATERIALS AND METHODS}

\section{Materials:}

Fresh bulk buffalo's milk and cream obtained from the herd of Faculty of Agriculture, Minoufia University, Shibin El. Kom, Egypt. Cream was obtained by separating fresh buffalo's milk in the pilot plant of Department of Dairy Science and Technoogy.

Stabilizer was obtained from Meer Corporation, North Bergen, NJ, USA. Sucrose and cocoa powder was obtained from the local markets.Skim milk powder was obtained from Hoogwegt international BV, Arnhenn, the Netherlands (Fat: 1.25\% max, Lactose: 56\% max, Ash $8.2 \%$ max, Moisture: 4\% max, Protein in MSNF: $34 \% \mathrm{~min}$ ).

\section{Preparationof mango's peel powder:}

Mango's fruits were obtained from the local market. Mango's fruits were washed by distilled water, then peeled and their edible portions were carefully separated. The healthy and fully ripe mango's peel were collected immediately after peeling, washed with distilled water to remove any foreign particles and blanched at $83^{\circ} \mathrm{C}$ for $5 \mathrm{~min}$ to avoid a browning reaction. The peels were spread out on trays and dried at $50^{\circ} \mathrm{C} \pm 2$ for $18 \mathrm{hr}$. using a conventional air oven (Hassan et al., 2011). The dried peels were ground carefully to pass through a $250 \mathrm{Mm}$ mesh, size sieve. The powder designated mango's peel powder (MPP) was packaged into air tight jars and kept at $4^{\circ} \mathrm{C}$ until analysis and use. The composition of mango's peel powderis shown in Table (1). 
Table (1). The gross compositions of mango's peel powder (MPP).

\begin{tabular}{|c|c|}
\hline Composition & Percentage (\%) \\
\hline Moisture & 5.2 \\
\hline Protein & 5.2 \\
\hline Fat & 3.8 \\
\hline Ash & 2.5 \\
\hline Total dietary fiber & 48.1 \\
\hline Carbohydrate & 35.2 \\
\hline
\end{tabular}

\section{Manufacture of ice cream:}

Chocolate ice milk mixes were prepared according to the method of Khader et al., (1992) with the following composition: $4 \%$ fat, $13 \%$ milk solid not fat, $15 \%$ sugar, $0.5 \%$ stabilizer, $3 \%$ Cocoa. Control ice milk treatment was made as described above, while the other four ice milk treatments were supplemented with $0.5,1,1.5$ and $2 \%$ mango's peel powder respectively. Chocolate ice milk mixes were heated at $69^{\circ} \mathrm{C}$ for $30 \mathrm{~min}$, cooled and then aged over night at $4^{\circ} \mathrm{C}$. All ice cream mixes were frozen in an experimental ice cream batch freezen (Cattabriga, Bolongia, Italy). The resultant frozen ice milk was packaged in plastic cups and kept in deep freezer at $-18^{\circ} \mathrm{C}$ for $24 \mathrm{hrs}$. forhandening. Frozen ice milk was stored at $-20^{\circ} \mathrm{C} \pm 2$ for 10 weeks.

\section{Physical and chemical analysis:}

Overrun of the ice milk was determined according to the method of Arbuckle (1986). The specific gravity of ice milk mixes and ice milk samples were determined according to Omar (2014). Weight per gallon of ice milk mixes in kilogram (kg) was directly calculated according to Arbuckle (1986). The melting resistance of ice milk was determined as described by Omar (2014).

\section{Chemical analysis:}

$\mathrm{pH}$ values, titratable acidity and fat content were determined according to ling (1963). Total solids, ash and Total proteinwere determined according to the methods described by A.O.A.C, (2010).

\section{Sensory evaluation:}

Ten panelists from the staff members and graduated students at the Department of Dairy Science and Technoogy, Department of Food Science and Technoogy, Faculty of Agriculture, Minoufia University evaluated the organoleptic properties of each batch of chocolate ice milk at zero time and every two weeks of storage period according to score sheets described by Kebary and Hussein (1997).

\section{Statistical analysis:}

Data were analyzed using the completely randomized block design and $2 \times 3$ factorial design. Newman-keels. Test was used to make the multiple comparisons (Steel and Torrie, 1980) using Costat program. Significant differences were determined at $p \leq 0.05$. 


\section{RESULTS AND DISCUSSIONS}

\section{Properties of Ice milk mix:}

Titratable acidity of ice milk mixes is shown in Table (2). The obtained results revealed that there were no significant ( $p$ $>0.05$ ) differences among ice milk mixes which means adding mango's peel powder to chocolate ice mixes did not have significant $(p>0.05)$ effect on the titratable acidity of chocolate ice milk mixes (Table 2).

Specific gravity and weight per gallon followed similar trends (Table 2) (Hamed et al., 2014 and Kebary et al., 2018). Specific gravity and weight per gallon increased by adding mango's peel powder and this increase was proportional to the rate of adding mango's peel powder (Table 2). These results might be due to the increase of total solids of chocolate ice milk mixes (Hamed et al., 2014 and Kebary et al., 2018). Chocolate ice milk mix that made with the highest amount of mango's peel powder had the highest specific gravity and weight per gallon and were significantly $(p \leq 0.05)$ different from those of control chocolate ice milk mix that made without adding mango's peel powder (Table 2).

\section{Properties of chocolate ice milk:}

Overrun is evident from the data in Table (3) that overrun decreased by increasing the amount of added mango's peel powder. This trend was also assured by the finding of Dervisoglu and Yazici (2006), and Deosarkar et al., (2016).

Chocolate ice milk treatments C,T1 and T2 were not significantly $(p>0.05)$ different from each other, which means adding mango's peel powder up to $1 \%$ did not have significant $(p>0.05)$ effect on the overrun of the resultant chocolate ice milk, while increasing the amount of added mango's peel powder above $1.0 \%$ caused a significant $(p \leq 0.05)$ reduction of the overrun of chocolate ice milk (Table 3). This decrease of overrun might be due to the increase of viscosity (FuentesAlventosa et al., 2009 and Elleuch et al., 2011), which subsequently suppress the ability of chocolate ice milk to retain air (Chang and Hartel 2002, Sofjan and Hartel 2004 and Meyer et al., 2011).

Table (2). Effects of supplementing ice milk with mango's peel powder on some properties of ice mix.

\begin{tabular}{|c|c|c|c|}
\hline Treatments $^{\circ}$ & Specific gravity & Weight per gallon & Acidity \\
\hline $\mathrm{C}^{*}$ & $1.1134^{\mathrm{E}}$ & $4.2153^{\mathrm{E}}$ & $0.241^{\mathrm{A}}$ \\
\hline $\mathrm{T} 1$ & $1.1236^{\mathrm{D}}$ & $4.2539^{\mathrm{D}}$ & $0.232^{\mathrm{A}}$ \\
\hline $\mathrm{T} 2$ & $1.1341^{\mathrm{C}}$ & $4.2937^{\mathrm{C}}$ & $0.231^{\mathrm{A}}$ \\
\hline T3 & $1.1446^{\mathrm{B}}$ & $4.3334^{\mathrm{B}}$ & $0.234^{\mathrm{A}}$ \\
\hline T4 & $1.2148^{\mathrm{A}}$ & $4.5992^{\mathrm{A}}$ & $0.235^{\mathrm{A}}$ \\
\hline
\end{tabular}

- Each value in the table was the mean of three replicates.

For each effect the different letters in the same column means the multiple comparisons are different from each other, letter $A$ is the highest mean followed by $B, C, \ldots$. etc. Significant at 0.05 level ( $p \leq$ 0.05).

* C: control, chocolate ice milk without any additives.

T1, T2, T3 and T4: chocolate ice milk treatments made by adding $0.5,1,1.5$ and $2 \%$ of mango's peel powder, respectively. 
Table (3). Effects of supplementing ice milk with mango's peel powder on some properties of ice milk.

\begin{tabular}{|c|c|c|c|c|c|c|}
\hline \multirow{2}{*}{ Treatments ${ }^{\circ}$} & \multirow{2}{*}{$\begin{array}{c}\text { Specific } \\
\text { gravity }\end{array}$} & \multirow{2}{*}{$\begin{array}{l}\text { Weight } \\
\text { per } \\
\text { gallon }\end{array}$} & \multirow[b]{2}{*}{ Overrun } & \multicolumn{3}{|c|}{ Melting resistance } \\
\hline & & & & $\begin{array}{c}\text { first } 60 \\
\text { min }\end{array}$ & $\begin{array}{l}\text { Next } 30 \\
\text { min }\end{array}$ & $\begin{array}{c}\text { Last } 30 \\
\min \end{array}$ \\
\hline$C^{*}$ & $0.7835^{\mathrm{D}}$ & $2.4362^{\mathrm{D}}$ & $70.54^{\mathrm{A}}$ & $38.4^{\mathrm{A}}$ & $45.6^{A}$ & $15.8^{\mathrm{E}}$ \\
\hline T1 & $0.8040^{C D}$ & $2.8546^{C D}$ & $70.22^{\mathrm{A}}$ & $37.6^{\mathrm{AB}}$ & $42.3^{B}$ & $19.6^{\mathrm{D}}$ \\
\hline T2 & $0.8343^{C}$ & $3.2344^{c}$ & $68.81^{A B}$ & $36.4^{\mathrm{B}}$ & $40.5^{c}$ & $22.3^{\mathrm{C}}$ \\
\hline T3 & $0.8943^{B}$ & $3.3858^{B}$ & $60.23^{C}$ & $36.5^{\mathrm{BC}}$ & $37.8^{\mathrm{D}}$ & $24.9^{\mathrm{B}}$ \\
\hline T4 & $0.9556^{A}$ & $3.6179^{A}$ & $55.19^{\mathrm{D}}$ & $35.1^{\mathrm{C}}$ & $36.3^{\mathrm{DE}}$ & $27.6^{A}$ \\
\hline
\end{tabular}

- Each value in the table was the mean of three replicates.

For each effect the different letters in the same column means the multiple comparisons are different from each other, letter $A$ is the highest mean followed by B, C, ...etc. Significant at 0.05 level ( $p \leq$ 0.05).

* C: control, chocolate ice milk without any additives.

T1, T2, T3 and T4: chocolate ice milk treatments made by adding $0.5,1,1.5$ and $2 \%$ of mango's peel powder, respectively.

Effect of mango's peel powder on specific gravity and weight per gallon of ice milk are presented in Table (3). Both Specific gravity and weight per gallon followed similar trends (Hamed et al., 2014 and Kebary et al., 2018). Supplementing chocolate ice milk with mango's peel powder caused a significant increase $(p \leq$ $0.05)$ of specific gravity and weight per gallon of the resultant ice milk. There was no significant difference $(p>0.05)$ between control ice milk and treatment T1 that was made with adding $0.5 \%$ mango's peel powder. On the other hand treatment T4 that was made with adding the highest amount $(2.0 \%)$ of mango's peel powder exhibited the highest specific gravity and weight per gallon and was significantly different ( $p \leq 0.05$ ) from those of other chocolate ice milk (Table 3). These results might be due to the increase of total solids and/or the reduction of the overrun of the resultant chocolate ice milk, where there is negative correlationamong specific gravity and weight per gallon and the overrun. These results are in accordance with those of (Hamed et al., 2014; Kebary et al., 2015; Kamaly et al., 2017 and Kebary et al., 2018).

The melting resistances of chocolate ice milk that was expressed as the rate of melting shown in Table (3). Supplementing chocolate ice milk with mango's peel powder caused a pronounce $(p \leq 0.05)$ reduction of the rate of melting, which means increase the melting resistance of the resultant chocolate ice milk at $60 \mathrm{~min}$ and the next $\mathbf{3 0} \mathrm{min}$ (Table 3). There was positive correlation between the amount of added mango's peel powder and the melting resistance of the resultant chocolate ice milk at $60 \mathrm{~min}$ and the next 30min (Table 3). These results could be attributed to the higher dietary fiber content of mango's peel powder (Dervisoglu and Yazici, 2006; Temiz and Yesilsu 2010; Crizel et al., 2014; Hamed et al., 2014) that increase the viscosity and 
the water holding capacity (FuentesAlventosa et al., 2009; Elleuch et al., 2011; Baddi 2012 and Akbari et al., 2016) which binds higher amount of water and left lowest amount of free water that can be melted faster than bound water, therefore increase the melting resistance. These results could be supported by the finding of (Temiz and Yesilsu 2010; Akalin et al., 2017, Kamaly et al., 2017, Kebary et al., 2018). On the other hand melting resistance of all chocolate ice milk treatments after the last $30 \mathrm{~min}$ decreased significantly ( $p \leq 0.05)$ and this decrease was proportional to the rate of adding mango's peel powder (Table 3). These results are in agreement with these reported by Kebary et al., (2015); Kamaly et al., (2017) and Kebary et al., (2018).

All ice cream treatments were not significantly $(p>0.05)$ different from each other in titratable acidity and $\mathrm{pH}$ value which means that supplementation of chocolate ice milk with mango's peel powder did not have significant effect on the titratable acidity of ice milk treatments (Table 4). Titratable acidity and $\mathrm{pH}$ value of all ice milk treatments did not change significantly during the storage period ( $p$ $>0.05$ ). Similar results were reported by Kebary et al., (2018).

Total solids and total protein contents of ice milk treatments made with supplementation with mango's peel powder increased significantly $(p \leq 0.05)$ (Table 5) by adding mango's peel powder. There was positive correlation between the rate of adding mango's peel powder and total solids content of the resultant chocolate ice milk (Table 5). (Abdullah et al., 2003; Soukoulis et al., 2009; Hamed et al., 2014; Ayar et al., 2018). On the other hand total solids content of all chocolate ice milk treatments did not change significantly $(p>0.05)$ during the storage period (Table 5). These results are in agreement with those reported by Hamed et al., (2014); kamaly et al., (2017) and Kebary et al., (2018).

Fat and ash contentsof ice milk treatments made with supplementation with mango's peel powder were not significantly different from that of control ice milk which means that supplementation with mango's peel powder did not affect significantly fat and ash contents ( $p>0.05$ ). Fat and ash contents of ice milk treatments did not change significantly during storage period (Table 6).

The scores of flavor, body and texture and total scores followed similar trends (Tables 7, 8). On the other hand there more no significant $(p>0.05)$ differences among all chocolate ice milk treatments of the scores of colour and melting quality, which means adding mango's peel powder did not have significant $(p>0.05)$ effect on the colour of the resultant ice milk (Tables 7, 8). The most acceptable chocolate ice milk treatments were T2 and T3 those made with adding 1.0 and $1.5 \%$ mango's peel powder. These treatments (T2 and T3) were not significantly ( $p>0.05)$ different from each other, while they were significantly ( $p \leq 0.05)$ different from the other treatments (C, T1, T4). These results indicate that supplementing of chocolate ice milk with mango's peel powder up to $1.5 \%$ improved significantly the organoleptic properties of chocolate ice milk (Tables 7, 8). The score of organoleptic properties (flavor, colour, melting quality, body and texture and total score) did not change significantly ( $p>$ 0.05 ) during the first 8 weeks of storage period then decreased during the last two weeks (Tables 7,8$)$. These results are in agreements with those reported by Kebary et al., (2004), Hamed et al., (2014), Kamaly et al., (2017) and Kebary et al., (2018). 

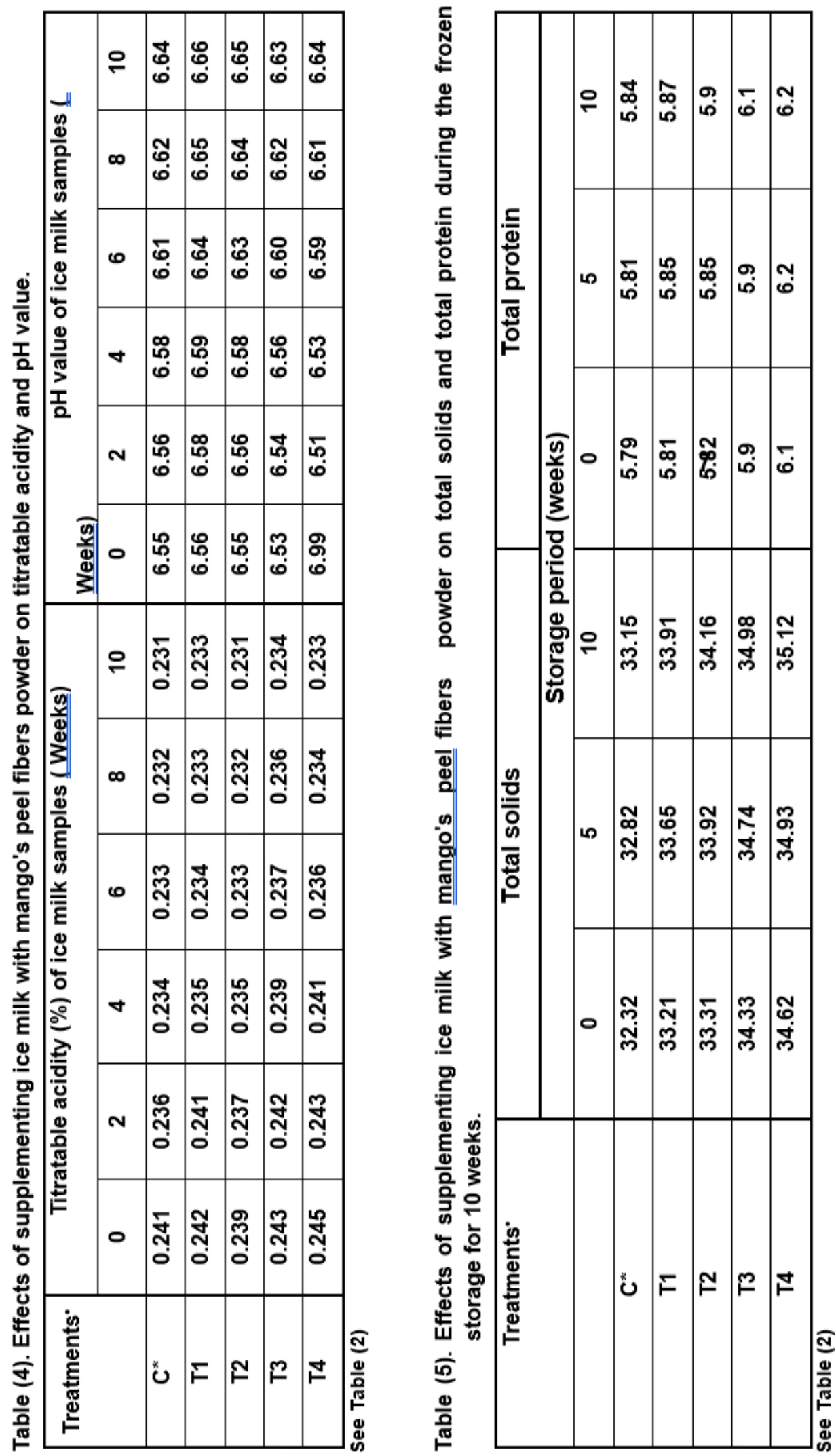


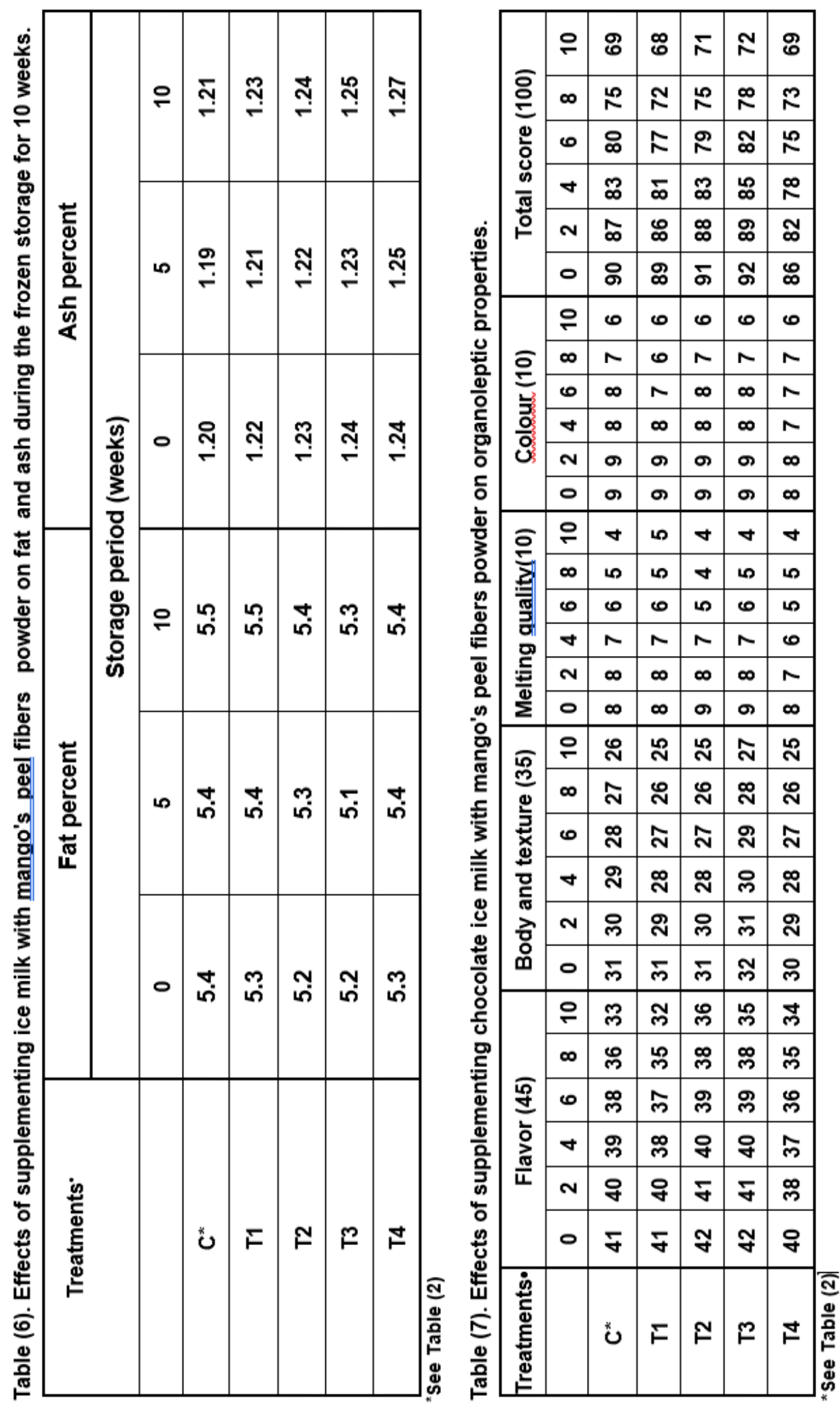




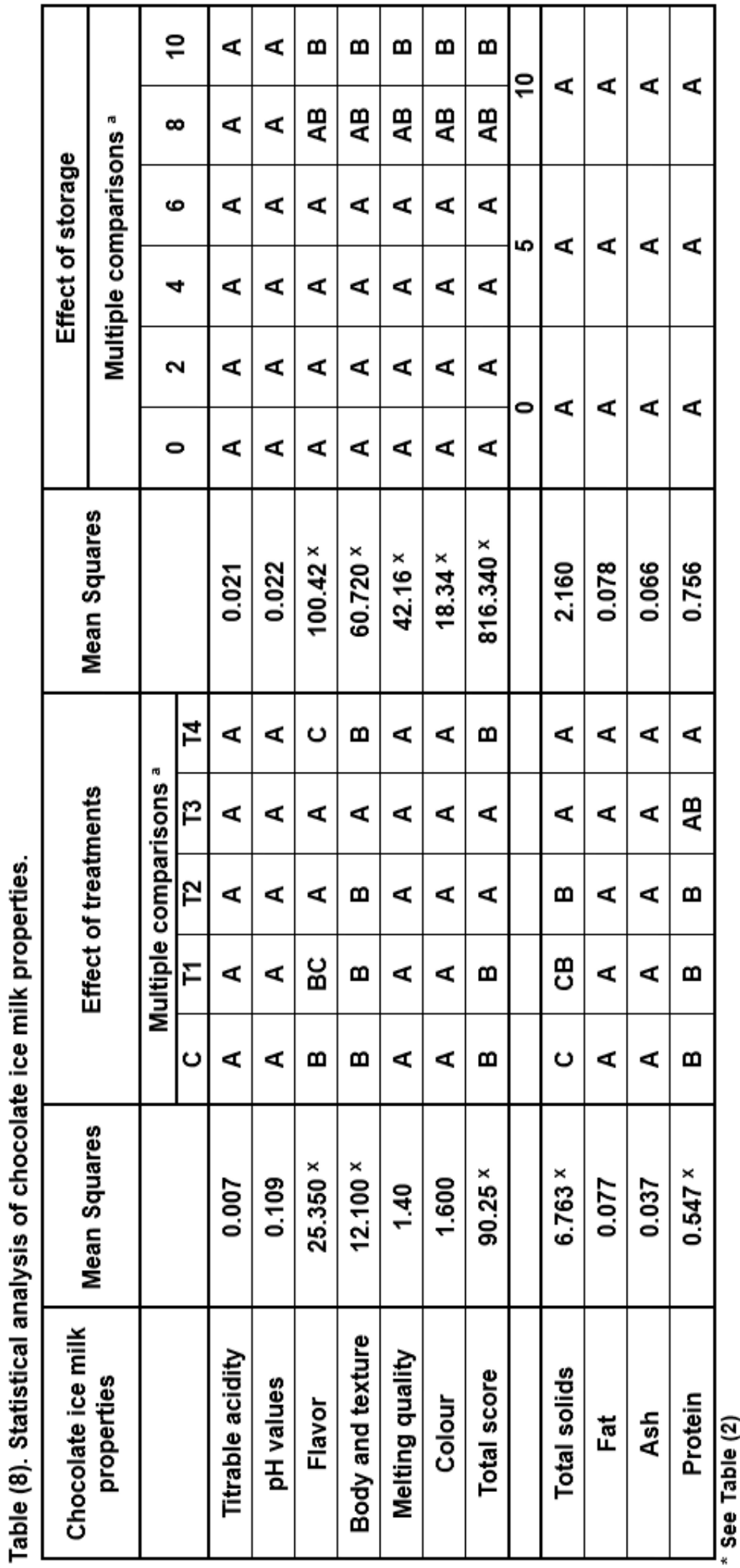


It could be concluded that supplemented chocolate ice milk with mango's peel powder up to $1.5 \%$ improved the melting resistance and the acceptability of the resultant chocolate ice milk, while did not have significant effects $(p>0.05)$ on acidity, fat and protein content. Therefore, it could be recommended that it is possible to make a good quality chocolate ice milk by adding up to $1.5 \%$ mango's peel powder without determinantal effects on chocolate ice milk quality.

\section{REFERENCES}

A.O.A.C. (2010). Official Methods of Analysis of Association of official Analytical Chemists. $18^{\text {th }}$ Edition, Washington, DC.Vol.6 No.10.

Abdullah, M., Z. H. Saleem-ur-Rehman, H. M. Saeed, S. Kousar and M. Shahid (2003). Effect of skim milk in soy milk blend on the quality of ice cream. Pakistan. J. Nutr., 2(5): 305-311.

Ahmadi, A., E. Milani, A. Madadlou, S.A. Mortazavi, R. R. Mokarram and D. Salarbashi (2014). Synbiotic yogurt-ice cream produced via incorporation of microencapsulated Lactobacillus acidophilus (la-5) and fructooligosaccharide. J. Food Sci.and Techno., 51(8): 1568-1574.

Ajila, C. M., S. G. Bhat and U. J. S. PrasadaRao (2007). Valuable components of raw and ripe peels from two Indian mango varieties. Food Chem., 102 (4):1006-1011.

Akalin, A. S., H. Kesenkas, N. Dinkci, G. Unal, E. Ozer and O. Kınık (2017). Enrichment of probiotic ice cream with different dietary fibers: Structural characteristics and culture viability. $J$. Dairy Sci., 10 (1):1-10.

Akbari, M., M.H. Eskandari, M. Niakosari and $A$. Bedeltavana (2016). The effect of inulin on the physicochemical properties and sensory attributes of low-fat ice cream. Inter. Dairy J., 57(3): 52-55.

Arbuckle, W.S. (1986)."Ice cream". $4^{\text {th }}$ Ed., The AVI Publishing Co. INC. Westport, Connecticut, U.S.A.

Arbuckle, W.S. (2013)."Ice cream". $4^{\text {th }}$ Ed. USA: Springer Science \& Business Media.

Ayar, A., Sicramaz, S. Ozturk and Suzan 0. Yilmaz (2018). Probiotic properties of ice creams produced with dietary fibers from by-products of the food industry.Inter.J. Dairy Technoo., 71(1): 174-182.

Baddi, J. (2012). Extraction of total polyphenols and dietary fibre from mango peel and its application in selected food products. Food Sci. Depart. M.Sc. Thesis, Univ. Agric. Sci. Bangalore.

Beerh, O.P.; Raghuramaiah, B.; Krishnamurthy, G.V. and Giridhar, N. (1976).Utilization of mango waste: recovery of juice from waste pulp and peel. J. Food Sci. and Techno., 13 (23): 138-141.

Behall, K. M., D.J. Scholfield and J. Hallfrisch (2006). Whole-Grain diets reduce blood pressure in mildly Hypercholesterolemic men and women.J. Am.Diet Assoc., 106 (9):1445-1449.

Chang, Y. and R.W. Hartel (2002). Development of air cells in a batch ice cream freezer. J. Food Eng., 55(1): 7178.

Crizel, T.M., R. R. Araujo, A. O. Rios, R. Rech and S. H. Fores (2014). Orange fiber as a novel fat replacer in lemon ice cream. Food Sci. and Techno., 34(2): 332-340.

Deosarkar, S.S., S.D. Kalyankar, R.D. Pawshe and C. Khedkar (2016). Ice Cream: Composition and Health Effects. The Encyclopedia of Food and Health., 3 (5): 385-390.

Dervisoglu, M. and F. Yazici (2006). The effect of citrus fibre on the physical, 
chemical and sensory properties of ice cream. Food Sci. Techno. Inter., 12 (2):159-164.

Desmedt, A. and H. Jacobs (2001). "Soluble fibre," in Guide to functional food ingredients Surrey, England: Food RA Leatherhead Publishing., 18 (4)112-140.

Elleuch, M., D. Bedigian, O. Roiseux, S. Besbes, C. Blecker and H. Attia (2011). Dietary fibre and fibre-rich by-products of food processing: Characterisation, Technoogical functionality and commercial applications:A review. Food Chem., 124(2): 411-412.

El-Soukkary, F.A.H., M.A. EL-Sahn and H.M.A. Mohamed (2000). Physicochemical and nutritional evaluation of mango seed kernel and its utilization for pan bread supplementation.Zagazig J. Agric. and Res., 27 (6):1319-1342.

FAO (2009). Annual production of mango fruits in Egypt, at the web page: http://www.fao.org/faostat/

Fuentes-Alventosa, J. M., G. RodríguezGutiérrez, S. Jaramillo- Carmona, J.A. Espejo-Calvo, J. Fernández-Bolaños, R. Guillén-Bejarano and A. JiménezAraujo(2009). Effect of extraction method on chemical composition and functional characteristics of high dietary fibre powders obtained from asparagus by products. J. Food Chem., 113 (2): 665- 692.

Hamed, A.I., K.M.K. Kebary, R.M. Badawi, O.M. Salem and Nevein S. Omar (2014). Manufacture of low fat prebiotic ice milk. MenoufiaJ.Agric. Res., 39 (4): 1317-1329.

Hassan, F.A., A. Ismail, A.A. Hamid, A. Azlan and S.H. Al-Sheraji (2011). Characterisation of fiber-rich powder and antioxidant capacity of Mangiferapajang K. fruit peels. Food Chem., 126 (1):283-288.

Kamaly, K.M., K.M.K. Kebary, A.H. ElSonbaty and Khadega R. Badawi
(2017). Quality of low fat prebiotic frozen yoghurt.Menoufia J. Food and Dairy sci., 2: 23-35.

Kebary, K.M.K. and S.A. Hussein (1997). Quality of ice cream as influenced by substituting non-fat dry milk wheybean proteins coprecipitates. Egyptian, J. Dairy Sci., 25(2):311-325.

Kebary, K.M.K., A.H. El-Sonbaty, K.M. Kamaly and Khadega R.M. Badawi (2018). Evaluation of quality attributes of low fat low sucrose symbiotic frozen yoghurt. Egyptian J. Dairy Sci., 46:119134.

Kebary, K.M.K., A.I. Hamed, R.M. Badawi, O.M. Salem and Nevein S. Omar (2015). Preparation and properties of low-fat ice milk fortified with inulin. Egyptian J. Dairy Sci., 43(2): 169-176.

Kebary, K.M.K., A.I. Hamed, O.M. Salem and E.T.A. Yousef (2004). Impact of frozen yoghurt ingredients its quality and survival of bifidobacteria.proc.the $9^{\text {th }}$ Egyption conf. for dairy Sci. Tech. milk and dairy products for a healthy future, Dokki, 9-11 October, Cairo, Egypt.

Khader, A. E., S. I. Farag, A.M. Moussa and A.M. El-Bataway (1992). The use of whey protein concentrate in ice cream mixes. Menuofia J. Agric. Res., 17: 637647.

Kim, H., J.Y. Moon, D.S. Lee, M. Cho, H.K. Choi, Y.S. Kim, A. Mosaddik and S.K. Cho (2010). Antioxidant and antiproliferative activities of mango (Mangiferalndica L.) flesh and peel. Food Chemistry, 121(2): 429-436.

King, D.E., A.G. Mainous and C.A. Lambourne (2012). Trends in dietary fiber intake in the United States,19992008.J Acad. Nutr Diet., 112 (5):642648.

Ling, E. R. (1963). A Text Book of dairy Chemistry, Vol.2 practical $3^{\text {rd }}$ ed. Chapman \& Hall, Ltd., London. 
Lunn, J. and J. L. Buttriss (2007). Carbohydrates and dietary fibre. Nutr.Bulletin., 32(1), 21-64.

Meyer, D., S. Bayarri and E. Costeil (2011). Inulin as texture modifier in dairy products. Food Hydrocolloids, 25(8): 1881-1890.

Omar, N.S.S. (2014). Studies on ice milk. Ph.D. Thesis. Fac.Agric, MenoufiaUniv, Egypt.

Ozcan, T. and O. Kurtuldu (2014). Influence of dietary fiber addition on the properties of probiotic yogurt.Inter.J. Chem. Eng. and Applica., 5 (5):397-417.

Pandiyan, C., R. Annal Villi, G. Kumaresan, B. Murugan and G. Rajarajan (2012). Effect of incorporation of inulin on the survivability of Lactobacillus acidophilus in synbiotic ice cream. Inter. Food Res. J., 19(4): 1729-1732.

Sofjan, Rosalina, P. and Hartel, Richard, W. (2004). Effects of overrun on structural and physical characteristics of ice cream. Inter. Dairy J., 14(3): 255262.

Soukoulis, C., D. Lebesi and C. Tzia (2009). Enrichment of ice cream with dietary fibre: Effects on rheological properties, ice crystallisation and glass transition phenomena. Food Chem., 115 (2): 665-671.

Steel, R. G. D. and J. H. Torrie (1980). Principles and Procedures of Statistics.A biometrical approach. $2^{\text {nd }}$ Ed. McGraw-Hill Book Co., New York.

Temiz, H. and A.F. Yesilsu (2010). Effect of pekmez addition on the physical, chemical and sensory properties of ice cream. Czech J. Food Sci., 28 (6): 538-546. 


$$
\text { جودة الايس كريم المدعم بقشر المانجو المجفف }
$$

خميس محمد كامل كعبارى، سامى عبدالرحمن حسين، رجب محمد بلوى ،

\author{
فاطمة الاهثان الدهثان
}

قسم علوم وتكنولوجيا الألبان -كلية الزراعة سشبين الكوم - جامعة المنوفية

الملخص العربى

إهتم البحث بدراسة تاثير تدعيم الآيس كريم بقشر المانجو المجفف وذلك بنسب مختلفة على بعض الخواص الكيميائية

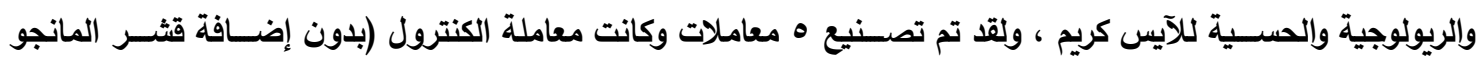

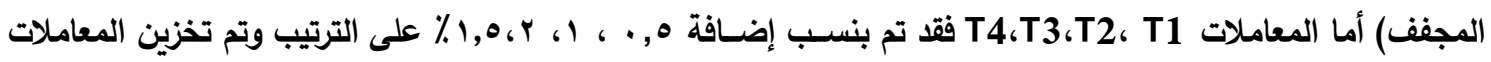

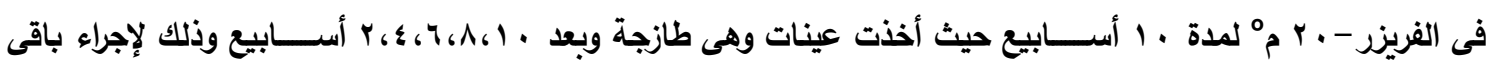

التحليلات الكيماوية والريولوجية والحسية عليها.

ولقد اوضحت النتائج المتحصل عليها بعد تحليلها احصائيا ما يلى :

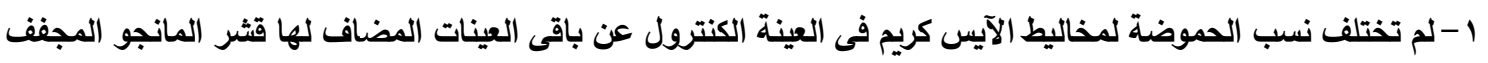

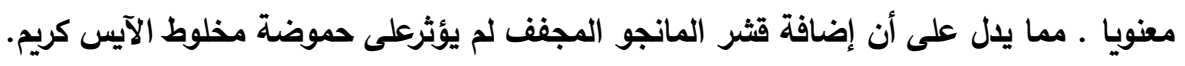
ץ- أدى إضافة قثر المانجوالمجفف إلى زيادة ملحوظة فى الوزن النوعى والوزن بالجالون لمخاليط الآيس كريم وهذه

الزيادة تتناسب طرديا مع معدل الإضافة.

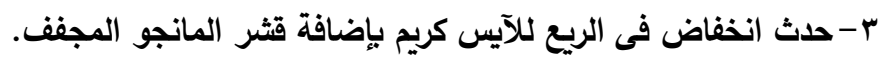

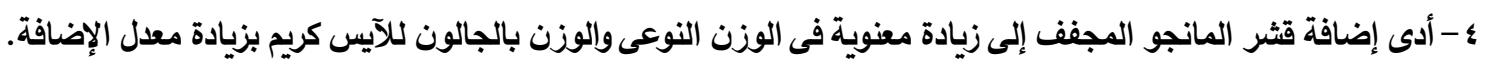

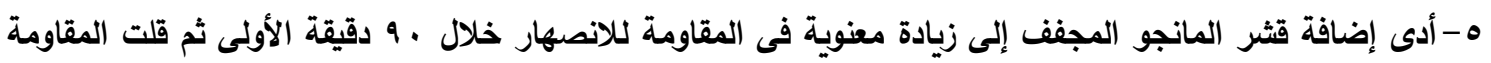

$$
\text { للانصهار فى أخر · ب دقيقة من التقدير. }
$$

צ-لم تختلف نسب الحموضة و pH فى العينة الكنترول عن العينات الآخرى المضاف إليها قثر المانجو المجفف معنويا وهذا يدل على أن إضافة قثر المانجو المجفف لم يؤثر على نسب الحموضة وpH للآيس كريم ولم تختلف آيضا أثناء فترة التخزين.

V-لم تختلف نسب الدهن والرماد فى العينة الكنترول عن العينات الاخرى المضاف إليها قثرالمانجوالمجفف معنويا مما يدل

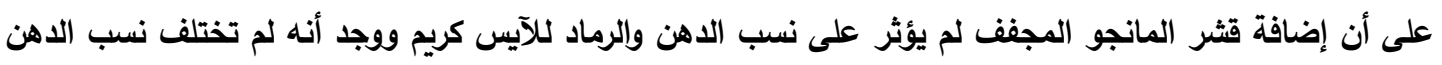
والرماد أثناء فترة التخزين. ^- أدى إضافة قثر المانجو المجفف للآيس كريم إلى زيادة الجوامد الكلية معنويا وعلى الجانب الأخر لم تتغير الجوامد الكلية أثناء فترة التخزين.

9- أضافة قثر المانجوالمجفف أدى الى زيادة معنوية فى البروتين الكلى ولكن البروتين لم يتاثر اثناء التخزين.

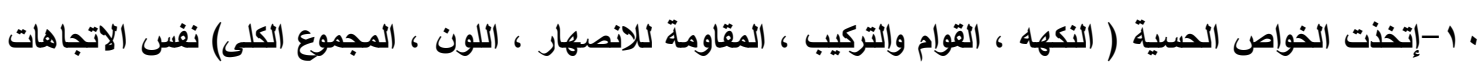

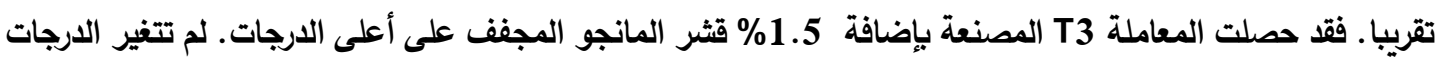

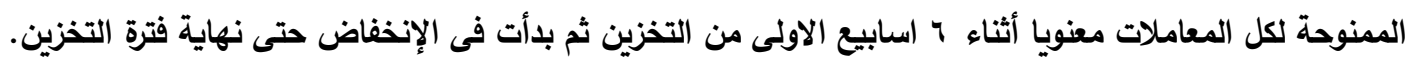

السادة المحكمين

أ.د / محمود عبدالحليم دغيدى كلية الزراعة - جامعة الفيوم ، أ.د/ على حسن السنباطــــ كلية الزراعة - جامعة المنوفية 